\title{
Implementation Discussion Learning in Learning Accounting Information System Course at State Polytechnic of Malang
}

\author{
Indrayati \\ Accounting Departement State Polytechnic of Malang, East Java, IndoneAIS
}

\begin{abstract}
Discussion is a scientific meeting to exchange ideas about a problem. The discussion discusses a topic of general concern where each group member has the same opportunity to ask questions and provide opinions. This research was the application of the discussion method and its influence on the effect of student learning outcomes in the AIS course in the Department of Accounting at Malang State Polytechnic. The results showed that the discussion method was successfully applied to AIS learning in the Department of Accounting, State Polytechnic of Malang with an excellent effect on student learning outcomes.
\end{abstract}

Keywords: Discussion method, student learning achievement.

DOI: $10.7176 / \mathrm{JEP} / 11-36-09$

Publication date: December $31^{\text {st }} 2020$

\section{INTRODUCTION}

The discussion method allows all students to have the opportunity to talk or dialogue with each other to exchange ideas and information about a topic or problem or look for possible facts and evidence that can be used for solving a problem. By using the discussion method in the teaching and learning process, it is hoped that students will be more active in learning so that students are more enthuAISstic and enthuAISstic about studying AIS and can apply it in everyday life.

Discussion is a communication interaction between two or more people (as a group). Usually, the communication between them / the group is in the form of one of the necessary knowledge or knowledge, which ultimately gives a good and correct sense of understanding. A discussion can be anything that was initially called a topic. From this topic, the discussion develops, is discussed, and in the end, produces an understanding of the topic.

The discussion method is a teaching method in which the teacher gives a problem or problem to students, and students are given the opportunity together to solve the problem with their friends. In the discussion, students can express opinions, deny other people's opinions, make suggestions, and make suggestions in order to solve problems in terms of various aspects.

The discussion method is a way of delivering learning material through the means of exchanging ideas to solve the problems at hand (Semiwan, 1990: 76). Meanwhile, according to Suryobroto (1997: 179) argues that the discussion method is a way of presenting teaching materials with the teacher to provide opportunities for students or groups to hold scientific conversations to gather opinions, make conclusions or develop various alternative solutions to a problem.

By implementing the discussion method, the classroom atmosphere will become more lively; each child is expected to participate actively. In the discussion, the role of the teacher/lecturer as a centre for providing information, giving assertiveness, determining boundaries can be reduced, so that the teacher/lecturer is only a traffic controller and a guide in carrying out the discussion, problem-solving is for all students. In contrast, the teacher/lecturer is an agent of enlightenment. The use of the previous learning method was the traditional method, or the lecture was less effective so that student achievement was not achieved as evidenced by the results of student achievement as follows:

Students get an A score of $25 \%$, a B + grade of $20 \%$, a B value of $15 \%$, a C + score of $20 \%$, a C score of $10 \%$ and a $\mathrm{D}$ value of $10 \%$.

So based on the description above, the researcher developed a new method, namely the discussion method in AIS learning in the Department of Accounting at Malang State Polytechnic.

\section{Application of the Discussion Method in Learning}

Discussion as a learning method is a process of involving two or more participants to interact with each other, exchange opinions, and or defend each other's opinions in problem-solving so that an agreement can be obtained between them. Learning that uses the discussion method is interactive learning. In the discussion method, there are groups as presenters of the material. Then there are audiences or other listeners as other groups as questioners in the discussion of the material being discussed.

The material presenter explains and presents the material studied in class, while the other group members act as questioners or rebutters of the material presented by the material presenter. It is hoped that with the discussion, all audiences can ask questions to the presenter so that the active discussion is an assessment of the success of 
learning the discussion method. With the discussion method, it can increase understanding of concepts and skills in studying science rather than the lecture method. The discussion method can also foster innovations or changes as well as new findings in learning and problem-solving.

Thus the discussion method is suitable, and the teacher/lecturer is needed to: 1) master the subject matter, 2) form and modify student attitudes, 3) problem solving, 4) help students think critically, 5) develop student learning motivation.

Several Types of Discussion Methods:

1) Large group discussion

2) Small group discussion

3) Panel discussion

4) Brain Storming group

5) Symposium

6) Informal debate

7) Colloqium

8) Fish Bowl

Purpose of the discussion method:

1) Encourage students to think critically

2) Encourage students to express their opinions freely

3) Encourage students to contribute their thoughts to solve problems together

4) Taking one alternative answer or several alternative answers to solve the problem based on careful consideration.

The advantages of the Discussion method are:

1) Educating students to learn to express their thoughts or opinions

2) allow students to obtain explanations from various data sources

3) allow students to experience the renewal of a problem together

4) Train students to discuss under the tutelage of the teacher/lecturer

5) Fostering a feeling of responsibility regarding an opinion, conclusion, or decision to be taken

6) Develop a sense of solidarity/tolerance for opinions that vary or may conflict

7) Fostering students to think carefully before speaking

The disadvantages of the discussion method are:

1) In-depth discussion takes much time

2) Not all topics can be used as material for discussion

3) Not all students dare to express their opinion

4) Discussion talks are only dominated by students who dare to speak

5) Allows a feeling of hostility between groups.

Several experts have researched Learning using the discussion method, including Sudarwati, 2017; Roni la'biran, 2017; Khalid Abdulbaki, 2018; Melody Daeli, 2019; Roy Cordean, 2001 and Ravi Setham Raju, 2014 with the results showing that the discussion method can improve student learning achievement.

\section{RESEARCH METHODOLOGY}

\subsection{Research Design}

Classroom Action Research

The Lewin model interpreted by Kemmis and Carr (2005) states that: Classroom Action Research is a form of reflective research carried out by actors in social society and aims to improve their work, understand the work and situations in which this work is carried out, including the field education. Classroom Action Research is also described as a dynamic process in which the four aspects of planning, action, observation and reflection must be understood. Figure 3.1 the Action Research Spiral by Kemmis \& Taggart, 1988 


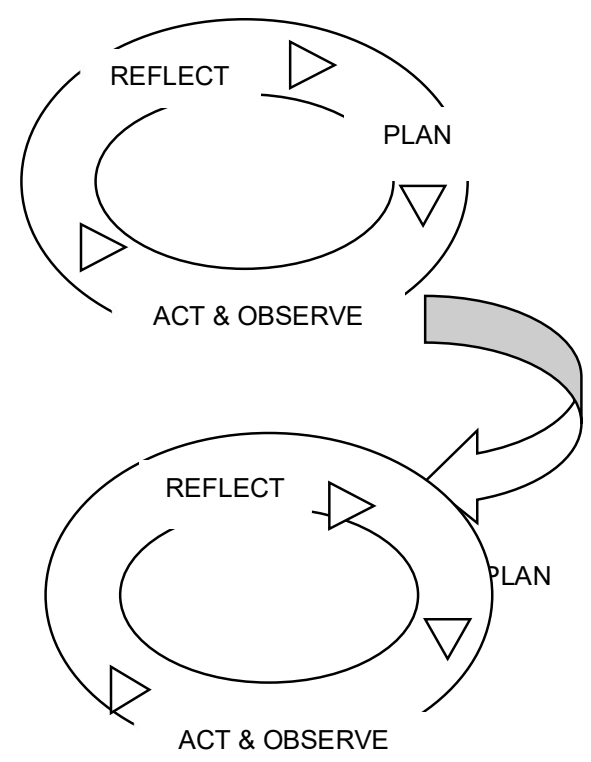

Revised Plan

Classroom action research, according to Moleong, 2006, is as follows:

identification of problems, discussion of problems between researchers and those under study, reviewing libraries and problems, redefining problems, choosing methods of change and evaluation, implementing changes.

3.2. The population and sample in this study were 400 students taking the Accounting Information System course, State Polytechnic of Malang. This type of research is qualitative-phenomenological-interpretive with a survey. With primary data sources and data collection methods are documentation from questionnaires, observation and discussion (focus group discussion) and triangulation and questionnaire tools.

\subsection{Procedure of the Classroom Action Research Plan.}

This research begins with a 'pre-test' after the research ends, a 'post-test' will be carried out. The research implementation procedure is based on (1) a general idea (General idea), which is to improve students' ability to understand Accounting Information Systems in an integrated manner followed by reconnaissance I (facts and findings analysis). (3) Then make a general plan (General plan) to be implemented and monitored. (4) Finally, reflection or reconnaissance II is made to see the failure and success of the implementation of the proposed learning model development (Kemmis in Elliot, 1991: 70).

\section{Result and Discussion}

\subsection{Development of learning models and classroom management}

In the development of this research carried out are:

1. Subject competency formulations have been made in the semester learning plan (RPS).

2. The syllabus has been made.

3. An outline of the lecture program (GBPP) in the Financial Accounting Practice course has been prepared for one semester.

4. A lecture program unit (SAP) which consists of chapters and sub-chapters will be taught during one semester of learning.

5. A module or Handout has been made and compiled teaching materials or learning materials that will be taught in each meeting or face-to-face for one semester.

6. Students actively study and understand handouts that have been made by the lecturers.

7. The pre-test is held in advance of understanding the material from the discussion that will be given.

8. The average group distribution for each class is 4-5 people per group.

9. An assignment/topic or learning project has been made to be given to students in one semester for the Accounting Information System course

10. Students are active and creative in discussing solving problems from each assignment/project that has been designed by the lecturer.

11. Creating results of observations into soft data, completion of findings.

12. A multi-media (CD-presentation) has been made, with power points as material for presentations in group discussions. 
13. Assess learning outcomes to determine the level of competence, quality, efficiency and effectiveness of the newly applied learning method.

14. Evaluation of discussion material and post-test in achieving / effectiveness of learning material.

15. Conduct learning assessment and evaluation systems, game rules and applied academic ethics.

In the management of this Accounting Information System learning, assessment or evaluation of students is also carried out by lecturers using the method suggested by Michaelson (1998), namely solving the assessment criteria into three performance areas, namely: 1) individual performance, 2) group performance and 3) the performance of individual contributions to the group (measured using a peer evaluation form). The amount, the composition of the scores have been discussed with students at the beginning of the lecture. Thus student could determine the weight of each component, but the lecturer determines the limit for the size of the weight. The process components and the results of the assessment of the student learning process are shown in table 3 .

$\begin{array}{cc}\text { Interval } & \text { Score } \\ 90-100 & \text { A } \\ 80-89 & \text { A- } \\ 74-79 & \text { B+ } \\ 65-73 & \text { B } \\ 60-65 & \text { C }+ \\ 50-60 & \text { C } \\ 39-50 & \text { D } \\ 0-39 & \text { E }\end{array}$

Source: Malang State Polytechnic Guidelines Book.

\subsection{Result and Discussion}

The results of the research on the implementation of the renewal of the learning model for the Accounting Information System course are the creation of competencies for the AIS course, the learning development plan (RPS), and the making of SILABI, GBPP, SAP, AIS teaching materials with power points and animation, textbooks from the implementation of AIS to MSMEs with the results of the assessment of the value ranking got an A score of $80 \%$, a B + value of $15 \%$ and a B value of $5 \%$. Meanwhile, the students' responses to the learning model of the new AIS course, namely discussion, were $90 \%$ agreeing to apply the discussion learning model, because this learning makes students active, innovative, creative, practical and fun, makes students more competent, understands AIS courses well in knowledge and skills. In comparison, 10\% are still happy with traditional learning, namely the lecture method.

This study implements a new learning method for the AIS course with the method of discussion and the use of teaching materials as well as practice questions and teaching aids using multi-media. Following are the results of interviews with students in the Discussion learning method for the Accounting Information Systems course.

Afrilia,

In my opinion, the AIS learning system with discussions is more accurate, efficient and effective. We will find it easier to understand the material then it is discussed so that it is easier to summarize the results of problem-solving after being discussed with all audience friends.

Aulia Shafira,

In my opinion, the AIS course is more suitable to use the discussion learning method because many things need to be discussed in order to find problem-solving results based on joint discussions.

Ayu Gigih,

I think learning based on group discussions can find a more concrete solution to problems because we understand what we learn and the findings of problems we can solve through collective discussion, not personal opinion.

Balqis Millenia,

In my opinion, learning the AIS course through discussion has made me more understandable to hear the opinions of several groups of friends, the insight has become more comprehensive.

Rise Priambada,

In my opinion, the discussion learning method is quite useful; it can make students more creative and innovative, as well as training students to be more courageous in speaking in front of many friends.

Dewi Nawang Kusuma,

In my opinion, with the discussion learning for AIS students, students become more active, creative, learning 
becomes more effective, innovative and fun because it encourages students to understand more about the concept of AIS and can later implement it in the real world.

Elina Amira,

In my opinion, the AIS course is quite dull because it is only a theory, so sometimes I feel sleepy, but with the discussion method, I am more motivated to ask questions, giving rise to the courage to reveal opinions in solving a problem.

Fahira Yolan,

In my opinion, the discussion method is more suitable to be applied to theoretical courses such as AIS so that students can better understand the concept in depth so that later they can apply it to the real world in companies or the business world.

Kevin Yuan,

In my opinion, the learning method of the AIS course is more suitable with the discussion method because it encourages students to be more active, innovative in solving problems that exist in the real world based on theoretical concepts.

Khusnul Khotrinah,

In my opinion, the discussion learning method is suitable to be applied to theoretical courses such as AIS which later we can apply to the real world/company.

Mardiana,

In my opinion, the AIS course is a theoretical course that we can understand in-depth by discussing with all our friends by giving different opinions then we can conclude together.

Marsya Rachmadewi,

In my opinion, with the discussion I am more enthusiastic, more courageous to express my opinion in solving problems related to cases that occur in the real world.

Moch. Iqbal zamzami,

I think this learning is more effective than the lecture method because we try to understand the concept of theory and then try to solve problems in cases related to theoretical concepts.

Monica Agusta,

In my opinion, with the discussion method, students are encouraged to deepen the concept of theory first. They can solve problems based on the theory for several cases or problems that must be discussed together.

Namira Anjani,

I think this method helps students to be more enthusiastic about learning, active, creative and innovative to be able to solve problems in cases that occur in the industrial or real world.

Natasya Kusuma,

In my opinion, in AIS learning, which also includes an information system that includes programming, it is better if the discussion method is used to help peers discuss information technology systems owned by classmates.

Ninda Abdiyatu,

In my opinion, the discussion method helps students to be more ready in class in learning a specific topic by expressing their opinions through discussion.

Nova Sari Kusuma Dewi,

In my opinion, I am more interested in the discussion method so that AIS learning in the class is not bored. Sometimes I feel sleepy when it comes to lecturing.

Pitaloka Restuningtyas,

In my opinion, it is more enjoyable to have a broader discussion of insight than studying alone and with lectures because we receive input from many friends and then conclude. 
Princess Tia Ayu,

In my opinion, this discussion method helps students to open their horizons more than just receiving lectures from lecturers.

Rafida Amalia,

In my opinion, the discussion raises the enthusiasm for learning to deepen the concept of theory and then solves problems by discussing with classmates so that the insight becomes broader.

Robi'atul Khoiriyah,

In my opinion, the discussion method creates a passion for active, creative and innovative learning, and learning becomes more efficient and effective.

Safina Miftakhunnisa,

In my opinion, discussion learning can encourage students to be more active in understanding theoretical concepts and dare to propose learning ideas to be more fun.

Akbar Password,

In my opinion, this discussion method stimulates students to dare to express their opinions in solving problems in the real world related to the theoretical concepts being studied.

Shandya Neta Karinda,

In my opinion, the discussion learning method is more suitable for AIS courses which must be practiced in the real world, so it needs an in-depth discussion to understand the concept.

Pure Siti,

In my opinion, this discussion method creates a conducive learning atmosphere that is more innovative so that it encourages students to submit different opinions and then conclude it together.

Tiara Firdausi,

I think learning by discussion will increase a deep understanding before the theory is put into practice in the world of work.

Wulan Sari,

In my opinion, learning becomes more fun with a pattern of discussion that encourages various opinions in solving a problem, which in the end is concluded as the final result of the problem solution.

\section{CONCLUSION AND RECOMENDATION}

Based on the research results, the conclusions obtained are:

The discussion learning method has been successfully applied in vocational education, namely the State Polytechnic of Malang. The creation of curriculum-based learning competencies (KKNI) through learning development plans (RPP) and syllabus.

The creation of a learning development plan in GBPP and SAP. The creation of textbooks and practice questions in learning Accounting Information Systems. The creation of teaching aids using multimedia in AIS learning. The survey results indicated that students preferred the Discussion learning method than the traditional lecture method.

Student scores are better than before with a composition that gets an A score of $80 \%$, a B + grade of $15 \%$, a B grade of $5 \%$.

\section{Research limitations}

This study is only on the application of the discussion method to accounting students of Malang State Polytechnic who are taking the AIS course.

\section{Acknowledgments}

It was delivered to the Director of Malang State Polytechnic (Dr Awan Setiawan, MM, MMT) for the funding of this research.

\section{REFERENCE}

Depdikbud. (1997). Pokok-pokok Pengajaran Biologi dan Kurikulum 1994. Jakarta: Depdikbud. Elliott, John, 1991. Action Research for Educational Change, Philadelphia: Open University Press.. Gelora Aksara 
Pratama

Http://haydar85.wordpress.com/2008/07/04/teori-belajar-behavioristik/

http://itachi. Student flein uns.ac.id/2009/09/08 macam-macam teori pembelajaran/

http://joegolan.wordpress.com/2009/04/13/teori-pembelajaran/

http://ukiakih.blogspot.com/2009/03/teori-belajar.html

J. Moleong, M.A. 2006. Metodologi Penelitian Kualitatif. Penerbit PT Remaja

Khalid Abdulbaki, Muhamad Suhaimi, Asmana Alsaggaf, Wafa Jawad, 2018, The Useof the Discussion Method at University:Enhancement of Teaching and Learning, International journal of Higher Education, Vol 7 No 6, 2018, DOI:10-5430/ijhe.v7n6p118.

Kinerja Guru dan Dosen, Program Pasca Sarjana Universitas Pendidikan IndoneAIS,

Melody Daeli, Sela Astarini, Hendra Huznussalam, 2019, Improving Speaking Skill Using Group Discussion, Project (Professional Journal of English Education), Vol 2 No 4, 2019, DOI:http://dx.doi.org/1022460/project.v2i4.p466-474.

Muhibbin, 2000, Metode pembelajaran Diskusi, Bandung, PT Remaja Rosdakarya.

Ravi Seetham Raju, 2014, Effectiveness of Using Online Discussion Forum for Case Study Analysis, Research Article, vol 2014, Article ID 589860, https://doi.org/10-1155/2014/589860.

Reni La'biran, 2017, Improving Speaking Ability Thruogh Small Group Discussion For The Eighth Year Students of SMPN 2 Saluputti in Tana Toraja, Elite:English and Literature Journal, Vol 4 No 1 , 2017.DOI:https://doi.org/10-24252/elite.v4i195.

Roy Cardean, 2001, Group Discussion and the Importance of a Shared perspective:Learning from collaborative research, first published Dec 1, 2001, https://doi,org/10-1177/146879410100100305.

Semiwan, 1990, Metode Pembelajaran Diskusi, Jakarta, PT Gramedia.

Soetomo. 1993. Dasar-dasar Interaksi Belajar Mengajar. Bandung: Usaha Nasional

Sudarwati, S.Khanafiyah, S.Sugiyanto, 2017, Online Course Development Vi Discussion Forum on Students of Physic Education Universitas Negeri Semarang, Jurnal Pendidikan Fisika IndoneAIS, Vol 13 No 2, 2017, DOI:https://doi.org.10-15294/jpfi.v3i1.8982.

Suherman, Erman, dkk. 2003. Strategi pembelajaran Matematika Kontemporer. Bandung:

Sulistiyono, Sri Kurnianingsih, Kuntatnti. 2005. Matematika XI Semester 2 Jakarta.

Suryobroto, 1990, Metode Pembelajaran Diskusi, Jakarta, PT Rineka Cipta.

Universitas Pendidikan IndoneAIS

Wiriatmadja-Rochiati, 2005. Metode Penelitian Tindakan Kelas, Untuk Meningkatkan

Kinerja Guru dan Dosen, Rosdakarya Bandung, IndoneAIS.

www. silabus. Web.id/Pembelajaran- diskusi/ 